\title{
Influence of Oxygen and Nitrate on Fe (Hydr)oxide Mineral Transformation and Soil Microbial Communities during Redox Cycling
}

\author{
Jacqueline Mejia ${ }^{\dagger}$, Eric E. Roden ${ }^{\ddagger}$, and Matthew Ginder-Vogel ${ }^{\star}, \dagger$ \\ †Environmental Chemistry and Technology Program, Department of Civil and Environmental \\ Engineering, The University of Wisconsin-Madison, 660 North Park Street, Madison, Wisconsin \\ 53706, United States \\ ¥Department of Geoscience, The University of Wisconsin-Madison, 1215 West Dayton Street, \\ Madison, Wisconsin 53706, United States
}

\section{Abstract}

Oscillations between reducing and oxidizing conditions are observed at the interface of anaerobic/ oxic and anaerobic/anoxic environments, and are often stimulated by an alternating flux of electron donors (e.g., organic carbon) and electron acceptors (e.g., $\mathrm{O}_{2}$ and $\mathrm{NO}_{3}{ }^{-}$). In iron (Fe) rich soils and sediments, these oscillations may stimulate the growth of both Fe-reducing bacteria $(\mathrm{FeRB})$ and $\mathrm{Fe}$-oxidizing bacteria $(\mathrm{FeOB})$, and their metabolism may induce cycling between $\mathrm{Fe}(\mathrm{II})$ and $\mathrm{Fe}(\mathrm{III})$, promoting the transformation of $\mathrm{Fe}$ (hydr)oxide minerals. Here, we examine the mineralogical evolution of lepidocrocite and ferrihydrite, and the adaptation of a natural microbial community to alternating Fe-reducing (anaerobic with addition of glucose) and Fe-oxidizing (with addition of nitrate or air) conditions. The growth of FeRB (e.g., Geobacter) is stimulated under anaerobic conditions in the presence of glucose. However, the abundance of these organisms depends on the availability of Fe(III) (hydr)oxides. Redox cycling with nitrate results in decreased $\mathrm{Fe}(\mathrm{II})$ oxidation thereby decreasing the availability of Fe(III) for FeRB. Additionally, magnetite is detected as the main product of both lepidocrocite and ferrihydrite reduction. In contrast, introduction of air results in increased $\mathrm{Fe}$ (II) oxidation, increasing the availability of $\mathrm{Fe}$ (III) and the abundance of Geobacter. In the lepidocrocite reactors, $\mathrm{Fe}$ (II) oxidation by dissolved $\mathrm{O}_{2}$ promotes the formation of ferrihydrite and lepidocrocite, whereas in the ferrihydrite reactors we observe a decrease in magnetite stoichiometry (e.g., oxidation). Understanding Fe (hydr)oxide transformation under environmentally relevant redox cycling conditions provides insight into

\footnotetext{
*Corresponding Author, Matthew Ginder-Vogel. mgindervogel@wisc.edu. Phone: 608-262-0768. Fax: 608-262-0454. ASSOCIATED CONTENT

Supporting Information

The Supporting Information is available free of charge on the ACS Publications website at DOI: 10.1021/acs.est.5b05519.

Detailed description of sample preparation and analysis by X-ray diffraction (XRD) and X-ray absorption spectroscopy (XAS). Additional figures and tables illustrate: an experimental summery (Table S1); nitrate concentration during redox cycling with nitrate (Figure S1); aqueous Fe(II) concentrations, total Fe(II) concentrations and Fe (hydr)oxide mineralogy in control Fe reducing reactors (Figure S2); taxa enriched by more than $1 \%$ in control Fe reducing reactors (Figure S3); EXAFS spectra and fits for solid samples (Figures S4, S5, and S6); XRD patterns of solid samples (Figures S7 and S8); and characterization of 16S clone libraries (Table S2) (PDF).

The authors declare no competing financial interest.
} 
nutrient availability and transport, contaminant mobility, and microbial metabolism in soils and sediments.

\section{Graphical Abstract}

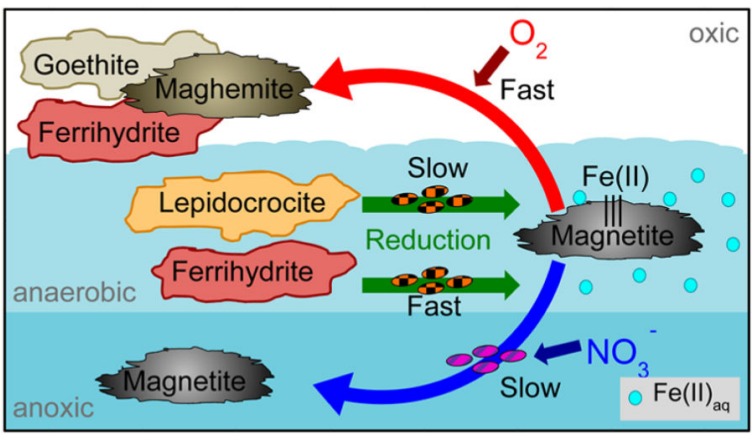

\section{INTRODUCTION}

Iron $(\mathrm{Fe})$ plays a major role in soil and sediment biogeochemical processes. ${ }^{1,2}$ The transition between $\mathrm{Fe}$ (II) and $\mathrm{Fe}$ (III) is of particular interest in dynamic environments that experience alternating reducing and oxidizing conditions. These variable conditions can be caused by shifts in the influx of electron donors (e.g., reduced organic carbon) and acceptors (e.g., nitrate and dissolved $\mathrm{O}_{2}$ ). Under anaerobic conditions, $\mathrm{Fe}(\mathrm{III})$ (hydr)oxides may be reduced by dissimilatory $\mathrm{Fe}$-reducing bacteria $(\mathrm{FeRB})^{3-5}$ or other reduced species, such as sulfide. ${ }^{6}$ Oxidation of $\mathrm{Fe}(\mathrm{II})$ is promoted by the presence of dissolved $\mathrm{O}_{2},{ }^{7}$ nitrite $\left(\mathrm{NO}_{2}{ }^{-}\right),{ }^{8}$ manganese oxides, ${ }^{9}$ and $\mathrm{O}_{2}$ or Fe-oxidizing bacteria $(\mathrm{FeOB}) .{ }^{10-12}$ Chemical and biological formation, transformation, and dissolution of Fe-bearing minerals occurs at the interface of reducing and oxidizing conditions, making an understanding of these reactions crucial for discerning environmental Fe mineralization pathways. Additionally, Fe (hydr)oxide mineral transformation directly impacts nutrient availability and transport, contaminant mobility, and microbial metabolism in soils and sediments. ${ }^{13-16}$

In natural environments, at circumneutral $\mathrm{pH}, \mathrm{Fe}(\mathrm{III})$ is generally present as solid-phase $\mathrm{Fe}(\mathrm{III})$ (hydr)oxides. ${ }^{17}$ The structure, solubility, bioavailability, and relative thermodynamic stability of these phases varies greatly depending on the biogeochemical conditions during their formation. ${ }^{17}$ Iron (hydr)oxide mineralogical transformations are relatively well characterized after a single reduction or oxidation cycle. ${ }^{18-21}$ For example, chemical or biological reductive dissolution of ferrihydrite results in magnetite or goethite formation, ${ }^{22-26}$ and aqueous $\mathrm{Fe}(\mathrm{II})$ oxidation by dissolved $\mathrm{O}_{2}$ or nitrate-dependent $\mathrm{Fe}$ oxidizing bacteria (NDFeOB) may result in ferihydrite, ${ }^{10,27}$ lepidocrocite, ${ }^{18}$ or even magnetite formation. ${ }^{28}$ However, these single condition studies are not representative of natural, redox-dynamic environments.

Many subsurface environments have redox transition zones where the temporary influx of dissolved $\mathrm{O}_{2}$ promotes the biological or chemical oxidation of $\mathrm{Fe}$ (II), generating $\mathrm{Fe}$ (III) for subsequent microbial $\mathrm{Fe}$ reduction in the presence of organic carbon or $\mathrm{H}_{2}$, under anaerobic conditions. ${ }^{29-31}$ Activity of Fe redox cycling microbial communities is observed in soils and 
sediments that experience these shifts in electron donors and acceptors. ${ }^{32-34}$ Additionally, recent studies illustrate that depending on reaction conditions, natural Fe(III) (hydr)oxide crystallinity can increase and mineral surface properties change throughout continuous redox cycling. ${ }^{35,36}$ The mobility and speciation of contaminants associated with $\mathrm{Fe}$ (hydr)oxides (e.g., U, Tc and As) is also affected by redox cycling conditions, although whether the metals are mobilized or retained depends on a large number of biogeochemical parameters. ${ }^{37-39}$ Overall, dynamic redox environments shape microbial communities, affecting both microbial and chemical Fe reduction and oxidation processes, and impacting Fe (hydr)oxide transformation pathways and the fate of associated nutrients and contaminants in soils and sediments. However, it is not clear how oxidation environment shape $\mathrm{Fe}$ (hydr)oxide transformations and soil microbial communities during redox cycling conditions.

Here we describe the transformation of lepidocrocite and ferrihydrite in the presence of a natural inoculum, under alternating reducing (anaerobic with addition of glucose) and oxidizing (with addition of dissolved $\mathrm{O}_{2}$ or nitrate) conditions. Powder X-ray diffraction (XRD) and X-ray absorption spectroscopy (XAS) are employed to determine Fe (hydr)oxide mineralogy, while sequencing of $16 \mathrm{~S}$ rRNA genes resolves microbial community composition throughout $\mathrm{Fe}$ redox cycling. Understanding Fe (hydr)oxide transformation during controlled biologically induced redox cycling provides insight into the biogeochemical transformation of iron, carbon, and nitrogen taking place in Fe-rich, redox active soil and sedimentary environments.

\section{MATERIALS AND METHODS}

\section{Fe (Hydr)oxide Synthesis}

Lepidocrocite was synthesized by titrating a $0.31 \mathrm{M}$ ferrous chloride solution to $\mathrm{pH} 6.8$ with $\mathrm{NaOH}$, while stirring and bubbling with air at a flow rate of $100 \mathrm{~mL} / \mathrm{min} .{ }^{40}$ Two-line ferrihydrite was synthesized by rapid titration of a $0.29 \mathrm{M}$ ferric chloride solution with $\mathrm{NaOH}$ to $\mathrm{pH}$ 7.0. The Fe (hydr)oxides were washed three times by centrifugation and freezedried (lepidocrocite) or suspended in anaerobic artificial groundwater (AGW) media (ferrihydrite). Ferrihydrite was used within 1 week of preparation to limit effects of mineral aging. X-ray diffraction (XRD) verified the presence of only the desired mineral phase in each of the starting materials.

\section{Inoculum Source}

Fresh surface sediment ( 0 to $30 \mathrm{~cm}$ ) was used as a natural microbial inoculum for the experiments and was collected from Dorn Creek, Dane County, WI. The sediment was sieved, diluted in AGW media, stored in amber bottles (Nalgene, NY) and used within 2 days of the collection date. The contribution of iron from the sediment to the total iron concentration in the reactors was less than $2 \%$.

\section{Experimental Setup}

Duplicate experiments consisted of $1 \mathrm{~L}$ of AGW media, $30 \mathrm{mM}$ Fe mineral (lepidocrocite or ferrihydrite), and $10 \mathrm{~mL}$ of inoculum. AGW media contained $0.5 \mathrm{mM} \mathrm{MgSO}_{4}, 0.20 \mathrm{mM}$ 
$\mathrm{Na}_{2} \mathrm{CO}_{3}, 0.50 \mathrm{mM} \mathrm{Ca}\left(\mathrm{NO}_{3}\right)_{2}, 0.05 \mathrm{mM} \mathrm{NH}_{4} \mathrm{Cl}, 0.05 \mathrm{mM} \mathrm{K}_{2} \mathrm{HPO}_{4}, 1 \mathrm{~mL} / \mathrm{L}$ trace metal solution, ${ }^{32} 0.1 \mathrm{~mL} / \mathrm{L}$ vitamin stock solution, ${ }^{32}$ and $10 \mathrm{mM}$ 1,4-piperazinediethanesulfonic acid (PIPES) buffer at $\mathrm{pH}$ 6.8. The media was boiled and bubbled with oxygen-free $\mathrm{N}_{2}$ (passed over hot $\mathrm{Cu}$-filings) for several hours before use. Reactors were sealed with thick butyl stoppers and remained in an anaerobic COY chamber $\left(95 \% \mathrm{~N}_{2}\right.$ and $\left.5 \% \mathrm{H}_{2}\right)$, in the dark, at room temperature, for the duration of the experiment. Reactors were thoroughly mixed during each sampling point; otherwise, they remained still. The glucose and nitrate stock solutions were sterilized in an autoclave at $122{ }^{\circ} \mathrm{C}$ for $20 \mathrm{~min}$ and were not degassed prior to addition to the reactors. All chemicals were ACS grade or better. Glassware was allowed to equilibrate for $24 \mathrm{~h}$ in the anaerobic chamber before use. Throughout the experiment, the $\mathrm{pH}$ remained at $7.1 \pm 0.2$ for all reactors.

Two sets of experiments were conducted in duplicate batch reactors to assess the impact of redox cycling on $\mathrm{Fe}$ (hydr)oxide mineral transformations and microbial community structure. (1) Fe redox cycling with nitrate was performed by addition of glucose (final concentration of $0.5 \mathrm{mM}$ ) on days $0,26,55$, and 79 to induce Fe(III) reduction, followed by addition of nitrate (final concentration of $2 \mathrm{mM}$ ) on days $21,49,74$, and 101 to induce $\mathrm{Fe}$ (II) oxidation. (2) Fe redox cycling with dissolved $\mathrm{O}_{2}$ was performed by addition of glucose (final concentration of $0.5 \mathrm{mM}$ ) on days $0,26,52$, and 77 to induce Fe(III) reduction, followed by exposure to air on days 21, 49, 74, and 101 to induce Fe(II) oxidation. Oxygen was introduced by rapidly stirring unsealed reactors outside the anaerobic chamber, continuously introducing dissolved oxygen. The solubility of dissolved oxygen at room temperature is $\sim 9 \mathrm{mg}-\mathrm{O}_{2} / \mathrm{L}$. Four redox cycles (Fe reduction followed by Fe oxidation) were carried out over 108 days (Table S1). Reduction half-cycles lasted for $\sim 19$ days (time in which $\mathrm{Fe}$ (II) production ceased), whereas oxidation half-cycles lasted either 5 days with nitrate (complete nitrate consumption) or 3 days with dissolved $\mathrm{O}_{2}$ (complete $\mathrm{Fe}$ (II) depletion). A control experiment to examine the transformation of lepidocrocite and ferrihydrite under strictly reducing conditions was investigated in the Fe reducing experiments, where glucose was added once to a final concentration of $0.5 \mathrm{mM}$ and oxidant was not added (Figures S2 and S3).

\section{Sampling and Analysis}

Reactors were sampled inside the anaerobic chamber by removing $1.5 \mathrm{~mL}$ of well-mixed slurry every 1 to 3 days and centrifuging (10000 rpm) for $5 \mathrm{~min}$. The supernatant was filtered through a $0.22 \mu \mathrm{m}$ PTFE filter; $100 \mu \mathrm{L}$ of the filtrate were then added to $1 \mathrm{~mL}$ of 0.6 $\mathrm{M} \mathrm{HCl}$ for aqueous $\mathrm{Fe}(\mathrm{II})$ quantification, and the remaining filtrate was preserved at $-18{ }^{\circ} \mathrm{C}$ for subsequent nitrate and nitrite analysis. Nitrate and nitrite were measured using a Dionex DX1000 ion chromatograph (IC) system, equipped with a 2100 Ion Pac AS9HC $4 \times 250 \mathrm{~mm}$ column, using $15 \mathrm{mM} \mathrm{NaOH}$ as the eluent. The solid pellet from the centrifugation was suspended in $1 \mathrm{M} \mathrm{HCl}$ for $1 \mathrm{~h}$ and then filtered through a $0.22 \mu \mathrm{m}$ filter. The $1 \mathrm{M} \mathrm{HCl}$ filtrate was collected for extractable, solid-associated $\mathrm{Fe}(\mathrm{II})$ quantification. $\mathrm{Fe}(\mathrm{II})$ was measured by adding $10-300 \mu \mathrm{L}$ of the $0.6 \mathrm{M} \mathrm{HCl}$ (aqueous $\mathrm{Fe}(\mathrm{II})$ ) or $1 \mathrm{M} \mathrm{HCl}$ (solid-associated $\mathrm{Fe}(\mathrm{II})$ ) sample to $5 \mathrm{~mL}$ of ferrozine solution $(1 \mathrm{~g}$ ferrozine dissolved in $1 \mathrm{~L}$ of $50 \mathrm{mM}$ HEPES buffer at $\mathrm{pH}$ 6). The mixture was kept in the dark for 10 min before measuring the 
absorbance at $562 \mathrm{~nm}$. Addition of aqueous Fe(II) and solid-associated Fe(II) represents total $\mathrm{Fe}(\mathrm{II})$ in the system.

\section{Solid-Phase Characterization}

Solid-phase samples were collected at the end of each redox half-cycle by filtering $35 \mathrm{~mL}$ of well-mixed slurry through a $0.22 \mu \mathrm{m}$ filter and drying it in a desiccator located inside the anaerobic chamber to avoid oxidation. Incomplete sample drying compromised the solidphase samples taken at the end of the first reduction period (day 21) and therefore this data is excluded from our analysis. Dried solids were analyzed by X-ray diffraction (XRD), and Match! software ${ }^{41}$ was used to determine which crystalline Fe phases were present in the sample. X-ray absorption spectroscopy (XAS) was carried out at the Fe K-edge $(7112 \mathrm{eV})$ to determine the relative percentages of the mineral phases using SIXPACK software (see SI for detailed description). ${ }^{42}$ Sample preparation for XRD and XAS analysis was performed inside the anaerobic chamber and samples were sealed prior to removing them from the chamber (details in SI). The Fe (hydr)oxide mineral standards used in linear combination fitting included two-line ferrihydrite $\left(\mathrm{Fe}(\mathrm{OH})_{3}\right)$, lepidocrocite $(\gamma$ - $\mathrm{FeOOH})$, goethite $(\alpha$ $\mathrm{FeOOH})$, maghemite $\left(\gamma-\mathrm{Fe}_{2} \mathrm{O}_{3}\right)$, and magnetite $\left(\mathrm{Fe}^{\mathrm{II}} \mathrm{Fe}_{2}{ }^{\mathrm{III}} \mathrm{O}_{4}\right)$. In our results, the presence of maghemite is due to partially oxidized or nonstoichiometric magnetite, rather than pure maghemite being present. ${ }^{43-46}$

\section{Microbial Community Analysis}

Slurry samples collected at day 0 and at the end of each reduction half-cycle were immediately frozen and stored at $-80^{\circ} \mathrm{C}$ after sampling. A MO BIO UltraClean Soil DNA kit was used to extract DNA from these samples and the samples were stored at $-80{ }^{\circ} \mathrm{C}$ immediately after extracting the DNA. The purified DNA was analyzed at the University of Wisconsin-Madison Biotechnology Center, where the V3-V4 region of the 16S rRNA gene was amplified and sequenced using Illumina MiSeq technology. Illumina reads were barcode-removed, filtered and paired-end merged using a PAired-eND Assembler for Illumina sequences (PANDAseq) ${ }^{47}$ Operational taxonomic units (OTUs) were assigned to sequences ( 0.97 threshold) by clustering the sequences (cd-hit) ${ }^{48}$ and assigning taxonomy (RDP classifier) ${ }^{49}$ using an established computational analysis pipeline from quantitative insights into microbial ecology (QIIME) ${ }^{50}$

\section{RESULTS}

\section{Iron Dynamics During Redox Cycling}

$\mathrm{Fe}$ (II) production is the result of microbial $\mathrm{Fe}$ (III) reduction and associated microbial processes (e.g., fermentation of glucose to short-chain organic acids, $\left.\mathrm{H}_{2}\right)^{51}$ linked to glucose metabolism by the natural inoculum. The Fe-reducing control experiments illustrate that once $\mathrm{Fe}(\mathrm{III})$ reduction ceases ( day 14) aqueous and solid $\mathrm{Fe}(\mathrm{II})$ concentrations remain at $0.61 \pm 0.09 \mathrm{mM}$ and $2.8 \pm 0.7 \mathrm{mM}$ for lepidocrocite and $1.6 \pm 0.3 \mathrm{mM}$ and $7.0 \pm 2 \mathrm{mM}$ for ferrihydrite for $\sim 45$ days (Figure S2). It became evident that one of the ferrihydrite reactors did not follow similar Fe(II) profiles as the rest of the reactors undergoing redox cycling with nitrate. The integrity of this reactor was compromised due to accidental damage to the reactor cap at day 21, causing aqueous and solid Fe(II) concentrations to be lower than 
expected throughout the entire experiment. The data obtained from this reactor after day 21 is not shown in Figure 1 and is excluded from our discussion.

In experiments undergoing redox cycling, at the conclusion of the first reduction period total $\mathrm{Fe}$ (II) concentrations are $6.3 \pm 0.6 \mathrm{mM}$ in the lepidocrocite reactors and $11.3 \pm 1.0 \mathrm{mM}$ in the ferrihydrite reactors (Figures 1 and 2). The aqueous phase of the lepidocrocite and ferrihydrite reactors contains $1.96 \pm 0.06$ and $2.2 \pm 0.2 \mathrm{mM}$ dissolved Fe(II), respectively (Figures 1 and 2). Upon introduction of either nitrate or dissolved $\mathrm{O}_{2}, \mathrm{Fe}(\mathrm{II})$ concentrations decrease due to oxidation (Figures 1 and 2).

Addition of $\sim 2 \mathrm{mM}$ nitrate oxidizes $0.9 \pm 0.3 \mathrm{mM}$ aqueous Fe(II) by the end of all four oxidation cycles in reactors containing either lepidocrocite or ferrihydrite. Solid-associated $\mathrm{Fe}(\mathrm{II})$ concentrations range between 1.4-9.9 mM in the lepidocrocite reactors and 1.4-12.5 $\mathrm{mM}$ in the ferrihydrite reactors throughout the experiment, and do not follow a clear oscillatory pattern associated with redox conditions (Figure 1). After all nitrate is consumed, introduction of glucose induces $\mathrm{Fe}(\mathrm{III})$ reduction, generating $0.7 \pm 0.2 \mathrm{mM}$ aqueous $\mathrm{Fe}$ (II) at the end of the second, third and fourth reduction cycles in all reactors.

$\mathrm{Fe}$ (II) oxidation is also observed during exposure to air, resulting in the oxidation of 6.3 $\pm 2.7 \mathrm{mM}$ total $\mathrm{Fe}$ (II) in all reactors, leaving dissolved Fe(II) below the ferrozine detection limit (Figure 2). Reduction of regenerated Fe(III) (hydr)oxides occurs in both the lepidocrocite and ferrihydrite reactors after restoration of anaerobic conditions and addition of glucose, resulting in production, on average, of $5.4 \pm 1.3 \mathrm{mM}$ total $\mathrm{Fe}$ (II) during the second, third and fourth reduction cycles (Figure 2). Although the total amount of $\mathrm{Fe}$ (II) produced in each reactor is similar, more $\mathrm{Fe}$ (II) partitions into the aqueous phase when lepidocrocite $(2.8 \pm 0.4 \mathrm{mM})$ is the starting mineral, instead of ferrihydrite $(1.6 \pm 0.4 \mathrm{mM})$.

\section{Iron (Hydr)oxide Mineralogy}

Because of limited data collection time, XAS data plotted in Figure S4 are from solids collected from only one reactor. However, we collected at least one scan for samples obtained from the duplicate reactors and in all cases the spectra are nearly identical to the spectra plotted in this manuscript. In the control Fe(III) reduction experiments, lepidocrocite persists as the dominant mineral phase throughout the entire experiment. Conversely, in the ferrihydrite reactors, magnetite is the dominant mineral phase (Figure S2).

In the experiments undergoing redox cycling with nitrate, $43 \mathrm{~mol} \%$ of lepidocrocite transforms into magnetite and $5 \mathrm{~mol} \%$ transforms into goethite at the end of the first oxidation period. The second reduction period results in the formation of $67 \mathrm{~mol} \%$ magnetite, $6 \mathrm{~mol} \%$ goethite and $2 \mathrm{~mol} \%$ ferrihydrite, whereas $25 \mathrm{~mol} \%$ lepidocrocite remains (Figure 1). Magnetite persists at $73-83 \mathrm{~mol} \%$ throughout the remainder of the experiment (Figure 1). Formation of $15 \mathrm{~mol} \%$ ferrihydrite is observed at the conclusion of the third oxidation period and likely serves as the precursor for the eventual formation of 25 mol \% goethite (Figure 1). When ferrihydrite is the starting mineral, it transforms predominantly into magnetite $(73 \mathrm{~mol} \%)$ and lepidocrocite $(10 \mathrm{~mol} \%)$ at the conclusion of the first nitrate oxidation period (Figure 1). More than $70 \mathrm{~mol} \%$ magnetite is present during 
the entire experiment, with the remainder ranging from 0-18 mol \% ferrihydrite and 0-13 mol \% goethite (Figure 1).

Introduction of dissolved $\mathrm{O}_{2}$ results in greater $\mathrm{Fe}(\mathrm{II})$ oxidation and formation of $\mathrm{Fe}(\mathrm{III})$ (hydr)oxide minerals such as lepidocrocite, ferrihydrite and maghemite (Figure 2). By the end of the first oxidation period, lepidocrocite transforms into $10 \mathrm{~mol} \%$ ferrihydrite, $7 \mathrm{~mol}$ $\%$ goethite and $46 \mathrm{~mol} \%$ magnetite, with $36 \mathrm{~mol} \%$ lepidocrocite remaining. As redox cycling proceeds, the amount of lepidocrocite gradually decreases to zero, as ferrihydrite (43 mol \%) and goethite (30 mol \%) increase, and magnetite (27 mol \%) decreases (Figure 2). When ferrihydrite undergoes redox cycling with dissolved $\mathrm{O}_{2}, 86-98$ mol \% magnetite is observed at the conclusion of the reduction periods, while oxidation periods result in the partial oxidation of magnetite and formation of 36-61 mol \% maghemite (Figure 2).

Depending on the redox conditions ferrihydrite (1-6 mol \%) and goethite (2-11 mol \%) are intermittently detected.

\section{Microbial Community Dynamics}

Initially, sequences that best match the aerobic soil taxa Cupriavidus ${ }^{52}$ (Table S2) comprise the largest component ( 14\%) of the 16S rRNA gene amplicon libraries; however, their relative abundance declines during redox cycling. Sequences closely related to Geobacter ${ }^{53}$ become prominent in all reactors by the end of the first reduction period (day 21, Figure 3). At the conclusion of the final redox cycle, Geobacter is more abundant in reactors undergoing redox cycling with dissolved $\mathrm{O}_{2}$ (16-28\% abundance) than those undergoing redox cycling with nitrate (4-9\% abundance). Redox cycling with nitrate results in the growth of NDFeOB, such as Dechloromonas $(\sim 1.5 \%),{ }^{12}$ and organotrophic nitrate reducers, including Propionivibrio ( 32\%), ${ }^{54}$ Sporomusa $(\sim 4.1 \%),{ }^{55}$ and Rhodocyclus $(\sim 7.9 \%)^{56}$ (Figure 3).

\section{DISCUSSION}

\section{Microbial Iron Redox Cycling}

Iron reducing bacteria $(\mathrm{FeRB})$ and $\mathrm{Fe}$ oxidizing bacteria $(\mathrm{FeOB})$ are commonly found in redox transition zones that experience temporary reducing or oxidizing conditions. ${ }^{32-35} \mathrm{In}$ the present study, the growth of FeRB is stimulated by the addition of glucose under anaerobic conditions, leading to microbial reduction of both ferrihydrite and lepidocrocite, and secondary mineralization (Figure 1 and 2). Under solely anaerobic conditions, after a single addition of glucose, $\mathrm{Fe}(\mathrm{III})$ reduction ceases after $\sim 14$ days and both aqueous and solid Fe(II) concentrations remain relatively constant for $\sim 45$ days (Figures S2 and S3). Additionally, 16S libraries illustrate that FeRB such as Geobacter, and bacteria involved in fermentation such as Clostridium and Propionivibrio, are enriched under these conditions (Figure S3).

Reactors undergoing redox cycling reveal that after $\sim 19$ days of the first reduction period, introduction of an oxidant (nitrate or dissolved $\mathrm{O}_{2}$ ) regenerates $\mathrm{Fe}(\mathrm{III})$ (hydr)oxides. However, the oxidation environment dictates the amount of $\mathrm{Fe}$ (II) oxidized and influences the microbial community dynamics. Specifically, nitrate additions ( $2 \mathrm{mM}$ final 
concentration) result in low $\mathrm{Fe}(\mathrm{II})$ oxidation. Under these conditions $\mathrm{Fe}(\mathrm{II})$ accumulates throughout the experiment, $\mathrm{Fe}(\mathrm{III})$ becomes limited and FeRB are outcompeted by organotrophic nitrate reducers. Conversely, high Fe(II) oxidation is observed during exposure to atmospheric oxygen. Regeneration of $\mathrm{Fe}(\mathrm{III})$ (hydr)oxides by dissolved $\mathrm{O}_{2}$ enhances the growth of FeRB during subsequent anaerobic conditions.

Despite being obligate anaerobes, Geobacter species are aerotolerant and commonly found in cyclically aerobic environments. ${ }^{34}$ Geobacter species also grow under cyclically anoxic conditions (e.g., nitrate input) alongside nitrate-dependent Fe oxidizing bacteria (NDFeOB), such as Dechloromonas species (Figure 3). ${ }^{32}$ However, the availability of $\mathrm{Fe}(\mathrm{III})$ (hydr)oxides to serve as terminal electron acceptors during redox cycling, greatly influences the growth of these organisms. ${ }^{3}$ Here, redox cycling with nitrate oxidizes $0.9 \pm 0.3 \mathrm{mM}$ aqueous $\mathrm{Fe}$ (II), while cycling with dissolved $\mathrm{O}_{2}$ oxidizes $6.3 \pm 2.7 \mathrm{mM}$ total $\mathrm{Fe}$ (II) during oxidation periods (Figures 1 and 2). Determining the exact amount of solid-associated $\mathrm{Fe}$ (II) oxidized by nitrate is difficult because there is not a clear transition between anaerobic and anoxic conditions in the amount of solid-associated Fe(II) (Figure 1). However, it is clear that dissolved $\mathrm{O}_{2}$ results in greater $\mathrm{Fe}(\mathrm{II})$ oxidation than nitrate.

In anoxic environments, at circumneutral $\mathrm{pH}$, the chemical oxidation of $\mathrm{Fe}$ (II) by nitrate is thermodynamically favorable, but not kinetically favorable. In our reactors, the decrease in aqueous Fe(II) (Figure 1) and nitrate (Figure S1) occur simultaneously, indicating that nitrate reduction is coupled to $\mathrm{Fe}(\mathrm{II})$ oxidation. Neutrophillic $\mathrm{NDFeOB}$ can catalyze the enzymatic transfer of electrons from $\mathrm{Fe}$ (II) to nitrate, in some cases leading directly to production of $\mathrm{N}_{2}$ by both pure and mixed cultures (eq 1). ${ }^{1,28}$

$$
10 \mathrm{Fe}^{2+}+2 \mathrm{NO}_{3}{ }^{-}+24 \mathrm{H}_{2} \mathrm{O} \rightarrow 10 \mathrm{Fe}(\mathrm{OH})_{3}+\mathrm{N}_{2}+18 \mathrm{H}^{+}
$$

However, the chemical reactions between $\mathrm{Fe}(\mathrm{II})$ and $\mathrm{NO}_{2}{ }^{-}$or $\mathrm{NO}$ (nitrate reduction intermediates) are thermodynamically and kinetically favorable at circumneutral $\mathrm{pH}$ and may also drive $\mathrm{Fe}$ (II) oxidation. ${ }^{8,57,58}$ The presence of $\mathrm{NO}_{2}{ }^{-}$was not detected by IC (detection limit $\sim 0.05 \mathrm{ppm}$ ), indicating that it was likely consumed by a combination of chemical $\mathrm{Fe}$ (II) oxidation and/or biological nitrite reduction. Overall, $\mathrm{Fe}(\mathrm{II})$ oxidation may be due to either enzymatic or chemical processes, or possibly a combination of both; unfortunately, this study was not designed to discern which pathway is dominant. The $16 \mathrm{~S}$ libraries reveal the enrichment of $\mathrm{NDFeOB}$ belonging to the genus Dechloromonas. However, denitrifying organisms such as Propionivibrio, ${ }^{54}$ Sporomusa, ${ }^{55}$ and Rhodocyclus ${ }^{56}$ are among the most abundant organisms (Figure 3). We suspect that the competition between organotrophic nitrate reducers and $\mathrm{NDFeOB}$ limits $\mathrm{Fe}(\mathrm{II})$ oxidation.

At circumneutral $\mathrm{pH}$, the half-life for dissolved $\mathrm{Fe}$ (II) is less than $5 \mathrm{~min}$ in air-saturated solutions. ${ }^{7}$ Accordingly, rapid chemical Fe(II) oxidation occurs in reactors undergoing redox cycling with dissolved $\mathrm{O}_{2}$, resulting in regeneration of $\mathrm{Fe}(\mathrm{III})$ (hydr)oxides, creating optimal conditions for the growth of Geobacter upon the onset of anaerobic conditions. In fact, 16S libraries show a greater abundance of Geobacter in the reactors exposed to dissolved $\mathrm{O}_{2}$ compared to those exposed to nitrate (Figure 3). Additionally, growth of $\mathrm{FeOB}$ is not 
expected or observed (Figure 3) due to the rapid chemical oxidation of $\mathrm{Fe}(\mathrm{II})$ by dissolved $\mathrm{O}_{2}{ }^{59}$ Oxygen-dependent FeOB (e.g., lithotrophic $\beta$-Proteobacterium strain TW2) are generally prevalent only under microaerophilic conditions, where dissolved $\mathrm{O}_{2}$ concentrations are low (less than $50 \mu \mathrm{M}) .{ }^{60}$

\section{Fe(III) (Hydr)oxide Transformation During Redox Cycling}

The amount of $\mathrm{Fe}$ (II) oxidized during the oxidation periods and the physiochemical nature of the $\mathrm{Fe}$ (hydr)oxide assemblage prior to further oxidation or reduction, are major factors influencing Fe (hydr)oxide transformation. The amount of Fe(II) oxidized controls the formation of fresh $\mathrm{Fe}(\mathrm{III})$ (hydr)oxide minerals, which may differ in crystal structure, particle size, surface area, solubility and bioavailability, influencing the rate of subsequent microbial Fe(III) reduction and the rate of electron injection and atom exchange by $\mathrm{Fe}(\mathrm{II})$ under anaerobic conditions. ${ }^{24,26,61,62}$

Microbial Fe(III) reduction during the anaerobic periods is evident in all reactors through the production of $\mathrm{Fe}$ (II) (Figures 1 and 2). In this study, $\mathrm{Fe}(\mathrm{III})$ reduction and $\mathrm{Fe}(\mathrm{II})$ oxidation are not expected under sterile conditions. In the presence of a natural inoculum it is hypothesized that FeRB can utilize Fe(III) (hydr)oxides as terminal electron acceptors and the fermentative metabolites of glucose (e.g., acetate) as electron donors. ${ }^{63}$ However, the extent of $\mathrm{Fe}$ (III) reduction is largely controlled by the properties of the Fe (hydr)oxide(s) present. For instance, during the first reduction period, due to its poorly crystalline structure and higher surface area, ferrihydrite is more bioavailable than lepidocrocite, resulting in greater microbial Fe(III) reduction and higher total Fe(II) concentrations (Figures 1 and 2). ${ }^{3,21,64} \mathrm{Fe}$ (II) drives mineral transformations via the transfer of electrons from $\mathrm{Fe}$ (II) to the solid phase and later atom exchange. ${ }^{24,26,62}$ At low Fe(II)/ferrihydrite ratios, dissolution/ reprecipitation of ferrihydrite results in the formation of lepidocrocite, and both ferrihydrite and lepidocrocite are precursors of goethite. ${ }^{26}$ Conversely, at high Fe(II)/ferrihydrite ratios magnetite is the end product of a topotactic transformation. ${ }^{26}$ The transformation pathway and ultimately its products also depend on the type of Fe mineral present. For example, in the presence of the same concentration of aqueous Fe(II), the transformation of ferrihydrite to magnetite is more rapid than the transformation of lepidocrocite to magnetite. ${ }^{65} \mathrm{In}$ fact, by day 49 more magnetite is observed in the ferrihydrite reactors than in the lepidocrocite reactors regardless of the redox cycling conditions (Figures 1 and 2).

Redox cycling with nitrate results in total $\mathrm{Fe}$ (II) concentrations above $\sim 3 \mathrm{mM}$ throughout the entire experiment. These elevated $\mathrm{Fe}$ (II) concentrations and long incubations provide enough time for the transformation of both lepidocrocite and ferrihydrite to magnetite to occur at circumneutral pH (Figure 1). ${ }^{26}$ Once magnetite becomes the dominant Fe (hydr)oxide, redox cycling of this mineral may result in the "charging" and/or "discharging" of the solid by storing or donating electrons. ${ }^{43}$ This "battery-like" behavior results in magnetite acting as a possible electron sink for FeRB or a donor for $\mathrm{FeOB}$ in the environment. ${ }^{43}$

When ferrihydrite is the starting mineral, the relative concentration of magnetite increases at the end of the second, third, and fourth nitrate induced oxidation periods (Figure 1). It is likely that glucose and/or its metabolites are not entirely consumed during the reduction periods, and that organotrophic denitrifiers consume the remainder during the oxidation 
periods, leaving metabolic potential for additional microbial Fe(III) reduction and Fe(II)mediated formation of magnetite even under anoxic conditions. Conversely, when lepidocrocite is subjected to redox cycling with nitrate, the presence of ferrihydrite is detected at the conclusion of the third oxidation period, and likely serves as a precursor for goethite formation toward the end of the experiment (Figure 1). ${ }^{66}$

Redox cycling with dissolved $\mathrm{O}_{2}$ mimics anaerobic environments that are periodically exposed to $\mathrm{O}_{2}$ due to variations in water table and other changes in geochemical conditions. ${ }^{60}$ At circumneutral $\mathrm{pH}, \mathrm{O}_{2}$ rapidly oxidizes $\mathrm{Fe}(\mathrm{II}),{ }^{67}$ depleting dissolved and solid-associated $\mathrm{Fe}(\mathrm{II})$ and resulting in the net production of $\mathrm{Fe}(\mathrm{III})$ (hydr)oxides (Figure 2). ${ }^{18,24,43}$ When lepidocrocite is the starting mineral, magnetite formation is expected due to $\mathrm{Fe}(\mathrm{III})$ reduction during the first reduction period; however, the quantity of magnetite decreases as ferrihydrite and goethite content increase throughout redox cycling (Figure 2). Compared to the ferrihydrite reactors, aqueous Fe(II) concentrations are higher in the lepidocrocite reactors prior to introduction of air. Higher aqueous Fe(II) concentrations may enhance the formation of ferrihydrite due to rapid oxidation of aqueous $\mathrm{Fe}$ (II) by dissolved $\mathrm{O}_{2}$. Under subsequent anaerobic conditions, ferrihydrite likely serves as the precursor for goethite (Figure 2). ${ }^{24,62}$

When ferrihydrite is the starting mineral, magnetite is the dominant mineral phase at the end of all reduction periods (Figure 2). Microbial Fe oxidation and reduction promotes the partial oxidation of magnetite (detected as an increase maghemite content in EXAFS spectra) and its subsequent reduction. ${ }^{43}$ In this study, exposure of the reduced solids (e.g., magnetite) to excess dissolved $\mathrm{O}_{2}$ results in $\mathrm{Fe}(\mathrm{II})$ oxidation, a change in the ratio of $\mathrm{Fe}(\mathrm{II})$ : $\mathrm{Fe}(\mathrm{III})$ and formation of maghemite (Figure 2). At the end of each oxidation period, the amount of total $\mathrm{Fe}$ (II) determined by ferrozine is considerably lower than what would be predicted from the amount of stoichiometric magnetite $\left(\mathrm{Fe}^{\mathrm{II}} \mathrm{Fe}^{\mathrm{III}}{ }_{2} \mathrm{O}_{4}\right)$. This disparity suggests the presence of non- $\mathrm{HCl}$ extractable $\mathrm{Fe}(\mathrm{II})$ within the mineral phase or that the magnetite detected is not stoichiometric. In environmental systems, maghemite often occurs as a weathering product of magnetite (eq 2). ${ }^{45,46}$ Magnetite is found in many soils and sediments and has a cubic inverse spinel structure, in which the tetrahedral sites are occupied by $\mathrm{Fe}^{3+}$ ions and the octahedral sites are occupied by equal $\mathrm{Fe}^{2+}$ and $\mathrm{Fe}^{3+}$ ions. ${ }^{46}$ The oxidation of magnetite is a topotactic reaction, where oxygen layers are added as Fe cations migrate to the surface. ${ }^{68,69}$ This nonstoichiometric magnetite remains with a cubic structure, contains partially occupied octahedral sites and can be used as a terminal electron acceptor for FeRB. ${ }^{68,69}$

$$
2 F e^{\mathrm{II}} \mathrm{Fe}^{\mathrm{III}}{ }_{2} \mathrm{O}_{4}+0.5 \mathrm{O}_{2} \rightarrow 3 \gamma-F e^{\mathrm{III}}{ }_{2} \mathrm{O}_{3}
$$

\section{Environmental Implications}

Our experiments illustrate that a microbial system undergoing repeated oscillations in the input of organic carbon (e.g., glucose) followed by oxidant (e.g., nitrate or dissolved $\mathrm{O}_{2}$ ) can develop a microbial community capable of mediating repeated $\mathrm{Fe}(\mathrm{III})$ reduction and $\mathrm{Fe}$ (II) oxidation at the interface of anaerobic/anoxic and anaerobic/oxic conditions. These results 
are similar to previous studies, ${ }^{10,32,34,60,70}$ and suggest that Fe cycling, microbial communities are not only present and active in surface environments that experience shifts in dissolved $\mathrm{O}_{2}$ but also in anoxic subsurface environments and/or nitrate-contaminated aquifers that experience shifts in organic carbon and nitrate input. ${ }^{31,71}$ Although redox cycling shapes microbial communities, it is also clear that alternating between reducing and oxidizing conditions also influences solution chemistry and thus impacts Fe (hydr)oxide mineralogy.

When nitrate is the oxidant, $\mathrm{Fe}$ (II) oxidation depends on the organic carbon loading, ${ }^{32}$ hence nitrate reduction may occur through organotrophic denitrification or nitrate-dependent $\mathrm{Fe}$ (II) oxidation. Competition between organotrophic and lithotrophic organisms may restrict $\mathrm{Fe}(\mathrm{II})$ oxidation, thereby depleting $\mathrm{Fe}(\mathrm{III})$ pools for subsequent microbial reduction, constraining cycling between $\mathrm{Fe}(\mathrm{II})$ and $\mathrm{Fe}(\mathrm{III})$. Our $16 \mathrm{~S}$ gene sequences demonstrate that redox cycling with nitrate triggers the growth of known FeRB (e.g., Geobacter) and NDFeOB (e.g., Dechloromonas); however, organisms that are not known to be involved in Fe reduction and oxidation (e.g., Propionivibrio) are more abundant. Oxidation with higher nitrate concentrations than used in this study may result in regeneration of additional $\mathrm{Fe}$ (III) and formation of $\mathrm{Fe}$ (III) (hydr)oxides, such as those observed with $\mathrm{O}_{2}$ oxidation. ${ }^{18}$ From a mineralogical perspective, a key aspect of this study is that both lepidocrocite and ferrihydrite transform primarily into magnetite. This finding has important implications for magnetite acting as an electron sink for sustaining microbial communities in oxygen-poor environments that undergo nitrate-driven redox fluctuations.

FeRB are known to be active in environments that experience temporal shifts in dissolved $\mathrm{O}_{2} \cdot{ }^{34}$ Here, the introduction of dissolved $\mathrm{O}_{2}$ generates poorly crystalline $\mathrm{Fe}(\mathrm{III})$ (hydr)oxides such as lepidocrocite and ferrihydrite, via chemical Fe(II) oxidation, and increases subsequent $\mathrm{Fe}(\mathrm{III})$ reduction by Geobacter upon transitioning to anaerobic conditions. When lepidocrocite is the starting mineral, the formation of ferrihydrite and goethite, illustrates that these Fe(III) minerals are readily accessible to FeRB and promote Fe redox cycling. Additionally, unlike the reactors undergoing redox cycling with nitrate, dissolved $\mathrm{O}_{2}$ can oxidize $\mathrm{Fe}(\mathrm{II})$ atoms in magnetite and promote the formation of nonstoichiometric magnetite during oxidation periods.

\section{Supplementary Material}

Refer to Web version on PubMed Central for supplementary material.

\section{Acknowledgments}

The authors thank Francisco Moya for assistance with 16S rDNA data analysis, Christopher Worley for assistance with IC analysis, and Christopher Formby for help with sample collection. We are also grateful with Elizabeth Tomaszewski, Francisco Moya, and Megan McConville for their comments, which improved the manuscript. We thank the scientists at GSE-CARS beamline 13-BMD at the Advanced Photon Source (APS), who are supported by the NSF-Earth Sciences division EAR-1129799 and the Department of Energy-GeoScience division DEFG02094ER14466. We also thank the scientists at beamline 4-1 at the Stanford Synchrotron Radiation Lightsource (SSRL) for their assistance with XAS data collection. Use of the Stanford Synchrotron Radiation Light-source, SLAC National Accelerator Laboratory, is supported by the U.S. Department of Energy, Office of Science, Office of Basic Energy Sciences under Contract No. DE-AC02-76SF00515. Jacqueline Mejia was supported by the Graduate Engineering Research Scholars and the Biotechnology Training Program (NIH 5T32-GM08349), from the 
University of Wisconsin-Madison. The contents of this publication are solely the responsibility of the authors and do not necessarily represent the official views of NIGMS or NIH.

\section{REFERENCES}

1. Weber KA, Achenbach LA, Coates JD. Microorganisms pumping iron: anaerobic microbial iron oxidation and reduction. Nat. Rev. Microbiol. 2006; 4(10):752-764. [PubMed: 16980937]

2. Melton ED, Swanner ED, Behrens S, Schmidt C, Kappler A. The interplay of microbially mediated and abiotic reactions in the biogeochemical Fe cycle. Nat. Rev. Microbiol. 2014; 12(12):797-808. [PubMed: 25329406]

3. Roden EE, Zachara JM. Microbial reduction of crystalline Iion(III) oxides: Influence of oxide surface area and potential for cell growth. Environ. Sci. Technol. 1996; 30(5):1618-1628.

4. Konhauser KO, Kappler A, Roden EE. Iron in microbial metabolisms. Elements. 2011; 7(2):89-93.

5. Lovley, D. Dissimilatory Fe(III)- and Mn(IV)-Reducing Prokaryotes. In: Dworkin, M.; Falkow, S.; Rosenberg, E.; Schleifer, K-H.; Stackebrandt, E., editors. The Prokaryotes. New York: Springer; 2006. p. 635-658.

6. Yao W, Millero FJ. Oxidation of hydrogen sulfide by hydrous Fe(III) oxides in seawater. Mar. Chem. 1996; 52(1):1-16.

7. Davison W, Seed G. The kinetics of the oxidation of ferrous iron in synthetic and natural waters. Geochim. Cosmochim. Acta. 1983; 47(1):67-79.

8. Klueglein N, Kappler A. Abiotic oxidation of Fe(II) by reactive nitrogen species in cultures of the nitrate-reducing $\mathrm{Fe}(\mathrm{II})$ oxidizer Acidovorax sp. BoFeN1 - questioning the existence of enzymatic Fe(II) oxidation. Geobiology. 2013; 11(2):180-190. [PubMed: 23205609]

9. Postma D. Concentration of Mn separation from Fe in sediments-I. Kinetics and stoichiometry of the reaction between birnessite and dissolved $\mathrm{Fe}(\mathrm{II})$ at $10^{\circ} \mathrm{C}$. Geochim. Cosmochim. Acta. 1985; 49(4):1023-1033.

10. Straub KL, Benz M, Schink B, Widdel F. Anaerobic, nitrate-dependent microbial oxidation of ferrous iron. Appl. Environ. Microbiol. 1996; 62(4):1458-1460. [PubMed: 16535298]

11. Chakraborty A, Roden EE, Schieber J, Picardal F. Enhanced growth of acidovorax sp. strain $2 \mathrm{AN}$ during nitrate-dependent $\mathrm{Fe}$ (II) oxidation in batch and continuous-flow systems. Appl. Environ. Microbiol. 2011; 77(24):8548-8556. [PubMed: 22003007]

12. Chakraborty A, Picardal F. Induction of nitrate-dependent Fe(II) oxidation by Fe(II) in dechloromonas sp. Strain 2AN. Appl. Environ. Microbiol. 2013; 79(2):748-752. [PubMed: 23144134]

13. Li Y, Yu S, Strong J, Wang H. Are the biogeochemical cycles of carbon, nitrogen, sulfur, and phosphorus driven by the "Fe-III-Fe-II redox wheel" in dynamic redox environments? J. Soils Sediments. 2012; 12:683-693.

14. Borch T, Kretzschmar R, Kappler A, Cappellen PV, Ginder-Vogel M, Voegelin A, Campbell K. Biogeochemical redox processes and their impact on contaminant dynamics. Environ. Sci. Technol. 2010; 44(1):15-23. [PubMed: 20000681]

15. Lovley DR, Coates JD. Bioremediation of metal contamination. Curr. Opin. Biotechnol. 1997; 8(3):285-289. [PubMed: 9206008]

16. Kaiser K, Guggenberger G. The role of DOM sorption to mineral surfaces in the preservation of organic matter in soils. Org. Geochem. 2000; 31(7-8):711-725.

17. Cornell, RM.; Schwertmann, U. The iron oxides: Structure, properties, reactions, occurences and uses. Weinheim, Germany: Wiley-VCH Verlag GmbH \& Co. KGaA; 2003.

18. Larese-Casanova P, Haderlein SB, Kappler A. Biomineralization of lepidocrocite and goethite by nitrate-reducing $\mathrm{Fe}(\mathrm{II})$-oxidizing bacteria: Effect of $\mathrm{pH}$, bicarbonate, phosphate, and humic acids. Geochim. Cosmochim. Acta. 2010; 74(13):3721-3734.

19. Stolz JF, Lovley DR, Haggerty SE. Biogenic magnetite and the magnetization of sediments. J. Geophys. Res. 1990; 95(B4):4355-4361.

20. Benner SG, Hansel CM, Wielinga BW, Barber TM, Fendorf S. Reductive dissolution and biomineralization of iron hydroxide under dynamic flow conditions. Environ. Sci. Technol. 2002; 36(8):1705-1711. [PubMed: 11993867] 
21. Hansel CM, Benner SG, Nico P, Fendorf S. Structural constraints of ferric (hydr)oxides on dissimilatory iron reduction and the fate of Fe(II). Geochim. Cosmochim. Acta. 2004; 68(15): 3217-3229.

22. Hansel CM, Benner SG, Neiss J, Dohnalkova A, Kukkadapu RK, Fendorf S. Secondary mineralization pathways induced by dissimilatory iron reduction of ferrihydrite under advective flow. Geochim. Cosmochim. Acta. 2003; 67(16):2977-2992.

23. Borch T, Masue Y, Kukkadapu RK, Fendorf S. Phosphate imposed limitations on biological reduction and alteration of ferrihydrite. Environ. Sci. Technol. 2007; 41(1):166-172. [PubMed: 17265943]

24. Boland DD, Collins RN, Miller CJ, Glover CJ, Waite TD. Effect of solution and solid-phase conditions on the $\mathrm{Fe}(\mathrm{II})$-accelerated transformation of ferrihydrite to lepidocrocite and goethite. Environ. Sci. Technol. 2014; 48(10):5477-5485. [PubMed: 24724707]

25. Eusterhues K, Hädrich A, Neidhardt J, Küsel K, Keller TF, Jandt KD, Totsche KU. Reduction of ferrihydrite with adsorbed and coprecipitated organic matter: microbial reduction by Geobacter bremensis vs. abiotic reduction by Na-dithionite. Biogeosciences. 2014; 11(18):4953-4966.

26. Hansel CM, Benner SG, Fendorf S. Competing Fe(II)-induced mineralization pathways of ferrihydrite. Environ. Sci. Technol. 2005; 39(18):7147-7153. [PubMed: 16201641]

27. Emerson, D. Microbial Oxidation of Fe(II) and Mn(II) at Circumneutral pH. In: Lovley, DR., editor. Environmental Microbe-Metal Interactions. Washington, DC: American Society of Microbiology; 2000. p. 31-52.

28. Chaudhuri SK, Lack JG, Coates JD. Biogenic Magnetite Formation through Anaerobic Biooxidation of Fe(II). Appl. Environ. Microbiol. 2001; 67(6):2844-2848. [PubMed: 11375205]

29. Silver WL, Lugo AE, Keller M. Soil oxygen availability and biogeochemistry along rainfall and topographic gradients in upland wet tropical forest soils. Biogeochemistry. 1999; 44(3):301-328

30. DeAngelis KM, Silver WL, Thompson AW, Firestone MK. Microbial communities acclimate to recurring changes in soil redox potential status. Environ. Microbiol. 2010; 12(12):3137-3149. [PubMed: 20629704]

31. Ratering S, Schnell S. Nitrate-dependent iron (II) oxidation in paddy soil. Environ. Microbiol. 2001; 3(2):100-109. [PubMed: 11321540]

32. Coby AJ, Picardal F, Shelobolina E, Xu H, Roden EE. Repeated anaerobic microbial redox cycling of iron. Appl. Environ. Microbiol. 2011; 77(17):6036-6042. [PubMed: 21742920]

33. Weber KA, Urrutia MM, Churchill PF, Kukkadapu RK, Roden EE. Anaerobic redox cycling of iron by freshwater sediment microorganisms. Environ. Microbiol. 2006; 8(1):100-113. [PubMed: 16343326]

34. Roden EE. Microbial iron-redox cycling in subsurface environments. Biochem. Soc. Trans. 2012; 40(6):1249-1256. [PubMed: 23176463]

35. Thompson A, Chadwick OA, Rancourt DG, Chorover J. Iron-oxide crystallinity increases during soil redox oscillations. Geochim. Cosmochim. Acta. 2006; 70(7):1710-1727.

36. Charlet L, Markelova E, Parsons C, Couture R-M, Madé B. Redox oscillation impact on natural and engineered biogeochemical systems: Chemical resilience and implications for contaminant mobility. Procedia Earth Planet. Sci. 2013; 7:135-138.

37. Law GTW, Geissler A, Burke IT, Livens FR, Lloyd JR, McBeth JM, Morris K. Uranium redox cycling in sediment and biomineral systems. Geomicrobiol. J. 2011; 28(5-6):497-506.

38. Yang J, Kukkadapu RK, Dong H, Shelobolina ES, Zhang J, Kim J. Effects of redox cycling of iron in nontronite on reduction of technetium. Chem. Geol. 2012; 291:206-216.

39. Parsons CT, Couture R-M, Omoregie EO, Bardelli F, Greneche J-M, Roman-Ross G, Charlet L. The impact of oscillating redox conditions: Arsenic immobilisation in contaminated calcareous floodplain soils. Environ. Pollut. 2013; 178:254-263. [PubMed: 23587855]

40. Schwertmann, U.; Cornell, RM. Iron Oxides in the Laboratory. Weinheim, Germany: Wiley-VCH Verlag GmbH; 2000. The Iron Oxides; p. 5-18.

41. Putz, H.; Brandenburg, K. Match! Phase Identification from Powder Diffraction. Bonn, Germany: CRYSTAL IMPACT; 2003.

42. Webb SM. SIXpack: a graphical user interface for XAS analysis using IFEFFIT. Phys. Scr. 2005; 2005(T115):1011. 
43. Byrne JM, Klueglein N, Pearce C, Rosso KM, Appel E, Kappler A. Redox cycling of Fe(II) and $\mathrm{Fe}(\mathrm{III})$ in magnetite by Fe-metabolizing bacteria. Science. 2015; 347(6229):1473-1476. [PubMed: 25814583]

44. Fischer H, Luster J, Gehring AU. EPR evidence for maghemitization of magnetite in a tropical soil. Geophys. J. Int. 2007; 169(3):909-916.

45. Fischer H, Luster J, Gehring AU. Magnetite weathering in a Vertisol with seasonal redoxdynamics. Geoderma. 2008; 143(1-2):41-48.

46. Guo H, Barnard AS. Modeling the iron oxides and oxyhydroxides for the prediction of environmentally sensitive phase transformations. Phys. Rev. B: Condens. Matter Mater. Phys. 2011; 83(9):094112.

47. Masella AP, Bartram AK, Truszkowski JM, Brown DG, Neufeld JD. PANDAseq: paired-end assembler for illumina sequences. BMC Bioinf. 2012; 13(1):31.

48. Li W, Jaroszewski L, Godzik A. Clustering of highly homologous sequences to reduce the size of large protein databases. Bioinformatics. 2001; 17(3):282-283. [PubMed: 11294794]

49. Wang Q, Garrity GM, Tiedje JM, Cole JR. Naïve Bayesian Classifier for Rapid Assignment of rRNA Sequences into the New Bacterial Taxonomy. Appl. Environ. Microbiol. 2007; 73(16): 5261-5267. [PubMed: 17586664]

50. Caporaso JG, Kuczynski J, Stombaugh J, Bittinger K, Bushman FD, Costello EK, Fierer N, Peña AG, Goodrich JK, Gordon JI, et al. QIIME allows analysis of high-throughput community sequencing data. Nat. Methods. 2010; 7(5):335-336. [PubMed: 20383131]

51. Lovley DR, Phillips EJ. Requirement for a Microbial Consortium To Completely Oxidize Glucose in Fe(III)-Reducing Sediments. Appl. Environ. Microbiol. 1989; 55(12):3234-3236. [PubMed: 16348080]

52. Vandamme P, Coenye T. Taxonomy of the genus Cupriavidus: a tale of lost and found. Int. J. Syst. Evol. Microbiol. 2004; 54(6):2285-2289. [PubMed: 15545472]

53. Straub KL, Hanzlik M, Buchholz-Cleven BEE. The use of biologically produced ferrihydrite for the isolation of novel iron-reducing bacteria. Syst. Appl. Microbiol. 1998; 21(3):442-449. [PubMed: 9779609]

54. Thrash JC, Pollock J, Torok T, Coates JD. Description of the novel perchlorate-reducing bacteria Dechlorobacter hydrogenophilus gen. nov., sp. nov. and Propionivibrio militaris, sp. nov. Appl. Microbiol. Biotechnol. 2010; 86(1):335-343. [PubMed: 19921177]

55. Dehning I, Stieb M, Schink B. Sporomusa malonica sp. nov., a homoacetogenic bacterium growing by decarboxylation of malonate or succinate. Arch. Microbiol. 1989; 151(5):421-426.

56. Smith RL, Buckwalter SP, Repert DA, Miller DN. Small-scale, hydrogen-oxidizing-denitrifying bioreactor for treatment of nitrate-contaminated drinking water. Water Res. 2005; 39(10):20142023. [PubMed: 15890383]

57. Carlson HK, Clark IC, Melnyk RA, Coates JD. Toward a mechanistic understanding of anaerobic nitrate-dependent iron oxidation: Balancing electron uptake and detoxification. Front. Microbiol. 2012; 3:34. [PubMed: 22363323]

58. Klueglein N, Zeitvogel F, Stierhof Y-D, Floetenmeyer M, Konhauser KO, Kappler A, Obst M. Potential role of nitrite for abiotic Fe(II) oxidation and cell encrustation during nitrate reduction by denitrifying bacteria. Appl. Environ. Microbiol. 2014; 80(3):1051-1061. [PubMed: 24271182]

59. Emerson D, Fleming EJ, McBeth JM. Iron-oxidizing bacteria: An environmental and genomic perspective. Annu. Rev. Microbiol. 2010; 64(1):561-583. [PubMed: 20565252]

60. Roden EE, Sobolev D, Glazer B, Luther GW. Potential for microscale bacterial Fe redox cycling at the aerobic-anaerobic interface. Geomicrobiol. J. 2004; 21(6):379-391.

61. Roden EE. Fe(III) Oxide Reactivity Toward Biological versus Chemical Reduction. Environ. Sci. Technol. 2003; 37:1319-1324.

62. Yee N, Shaw S, Benning LG, Nguyen TH. The rate of ferrihydrite transformation to goethite via the Fe(II) pathway. Am. Mineral. 2006; 91(1):92-96.

63. Lentini CJ, Wankel SD, Hansel CM. Enriched iron(III)-reducing bacterial communities are shaped by carbon substrate and iron oxide mineralogy. Front. Microbiol. 2012; 3:404. [PubMed: 23316187] 
64. Roden EE, Urrutia MM. Influence of biogenic Fe(II) on bacterial crystalline Fe(III) Oxide reduction. Geomicrobiol. J. 2002; 19(2):209-251.

65. Usman M, Abdelmoula M, Hanna K, Grégoire B, Faure P, Ruby C. FeII induced mineralogical transformations of ferric oxyhydroxides into magnetite of variable stoichiometry and morphology. J. Solid State Chem. 2012; 194:328-335.

66. Kappler A, Schink B, Newman DK. Fe(III) mineral formation and cell encrustation by the nitratedependent Fe(II)-oxidizer strain BoFeN1. Geobiology. 2005; 3(4):235-245.

67. Davison W, Seed G. The kinetics of the oxidation of ferrous iron in synthetic and natural waters. Geochim. Cosmochim. Acta. 1983; 47:67.

68. Gallagher KJ, Feitknecht W, Mannweiler U. Mechanism of oxidation of magnetite to $\gamma-\mathrm{Fe} 2 \mathrm{O} 3$. Nature. 1968; 217(5134):1118-1121.

69. Haneda K, Morrish AH. Magnetite to maghemite transformation in ultrafine particles. J. Phys. Colloq. 1977; 38(C1):C1-C321-C1-C323.

70. Straub KL, Schönhuber WA, Buchholz-Cleven BEE, Schink B. Diversity of ferrous iron-oxidizing, nitrate-reducing bacteria and their involvement in oxygen-independent iron cycling. Geomicrobiol. J. 2004; 21(6):371-378.

71. Postma D, Boesen C, Kristiansen H, Larsen F. Nitrate reduction in an unconfined sandy aquifer: Water chemistry, reduction processes, and geochemical modeling. Water Resour. Res. 1991; 27(8): 2027-2045. 
Starting mineral: Lepidocrocite
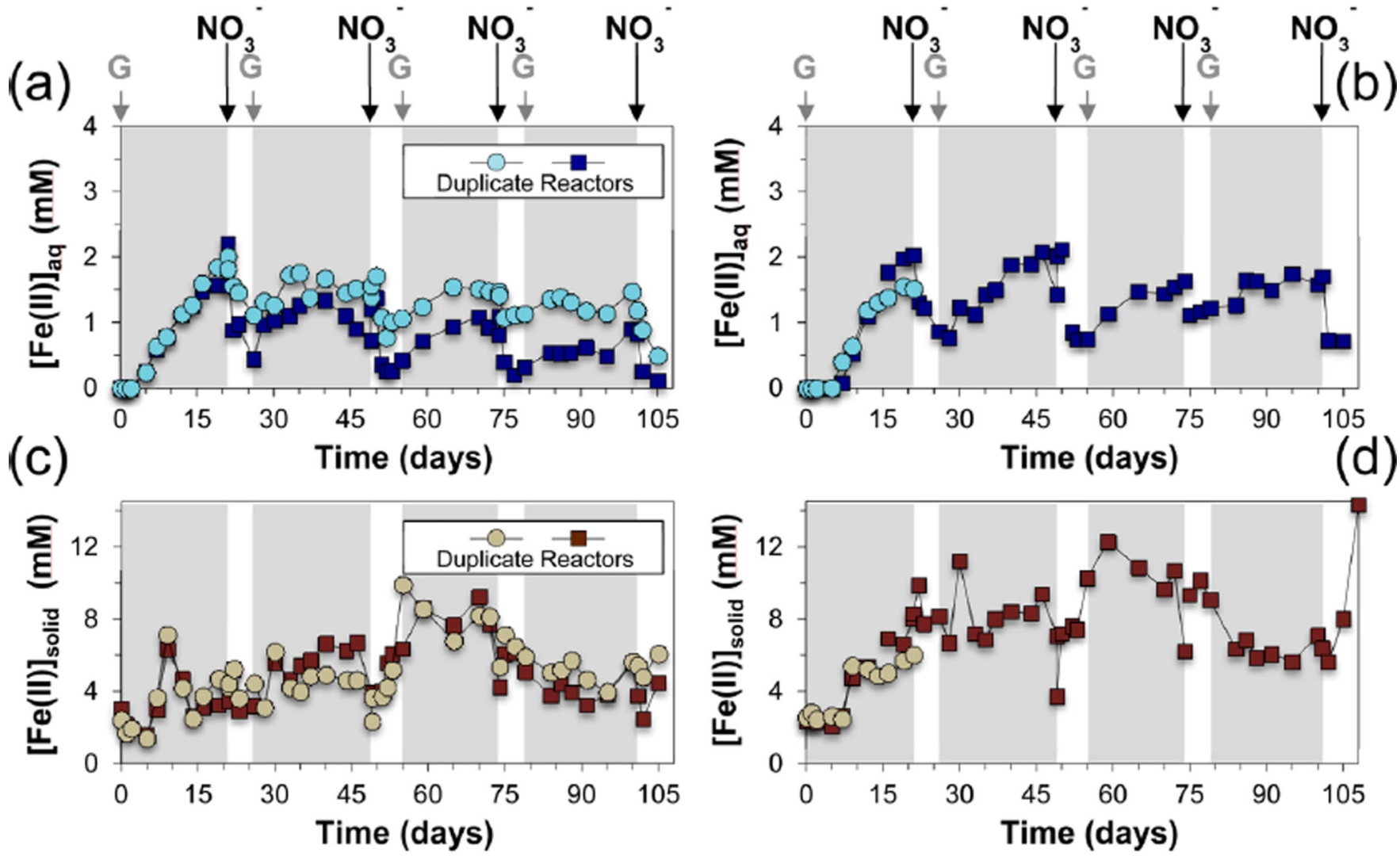

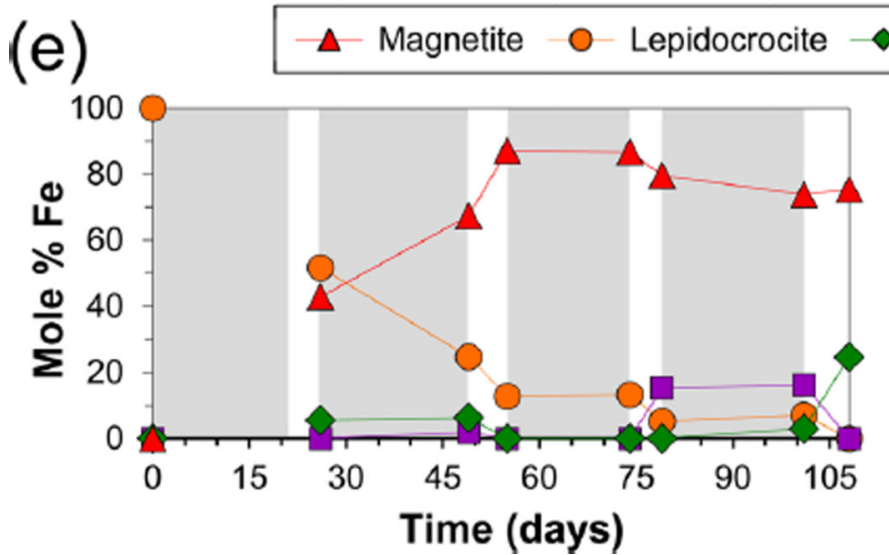

(e)

Goethite - Ferrihydrite $\boldsymbol{x}$-Maghemite

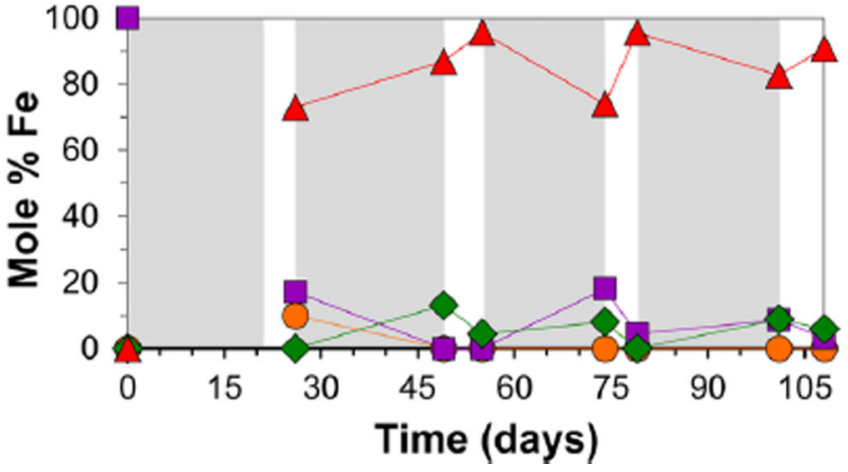

Figure 1.

Impact of redox cycling driven by introduction of glucose $(\mathrm{G})$, followed by nitrate $\left(\mathrm{NO}_{3}{ }^{-}\right)$ on aqueous $\mathrm{Fe}(\mathrm{II})$ (a, b), solid-associated $\mathrm{Fe}(\mathrm{II})$ (c, d) and $\mathrm{Fe}$ (hydr)oxide mineralogy (e, f) in reactors containing lepidocrocite $(\mathrm{a}, \mathrm{c}, \mathrm{e})$ or ferrihydrite $(\mathrm{b}, \mathrm{d}, \mathrm{f})$ as the starting minerals. EXAFS spectra and fits used to generate panels e and $\mathrm{f}$ are available in the SI. Anaerobic periods are shaded gray, while anoxic periods are in white. 
Starting mineral: Lepidocrocite

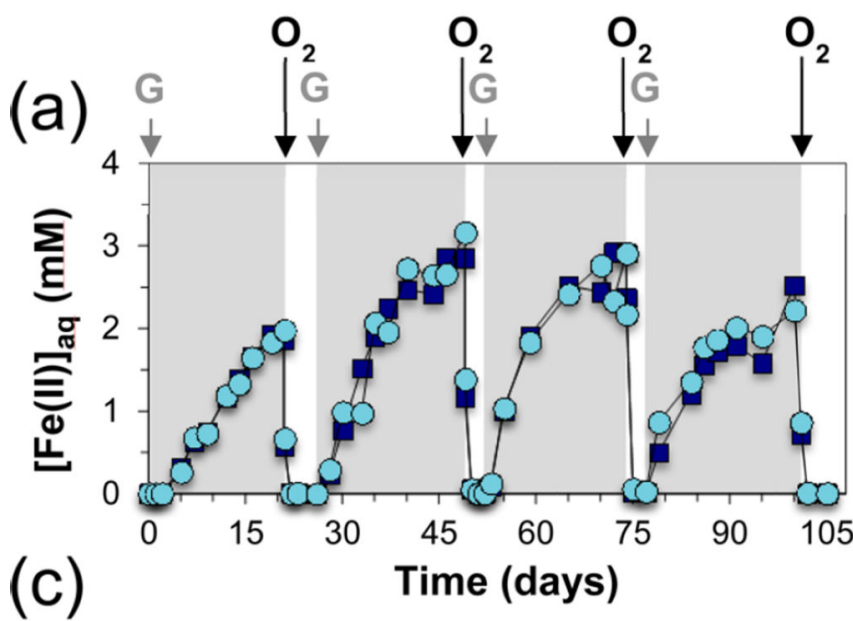

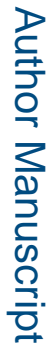

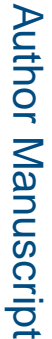

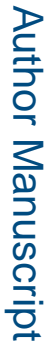

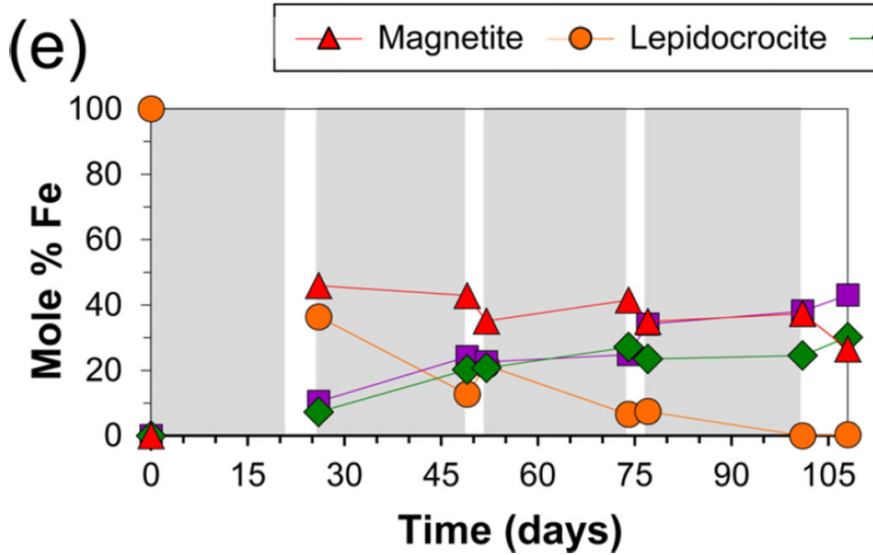

Figure 2. are shaded gray, whereas oxic periods are in white.

Starting mineral: Ferrihydrite
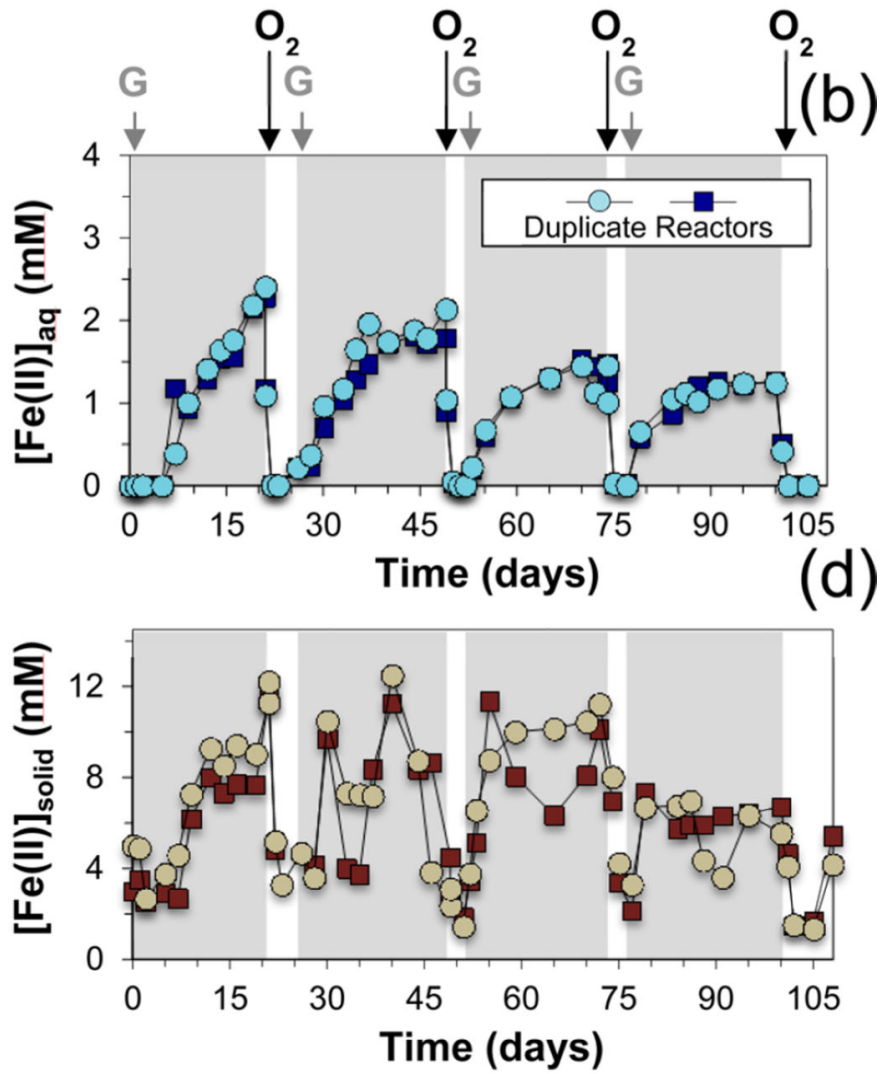

(f)

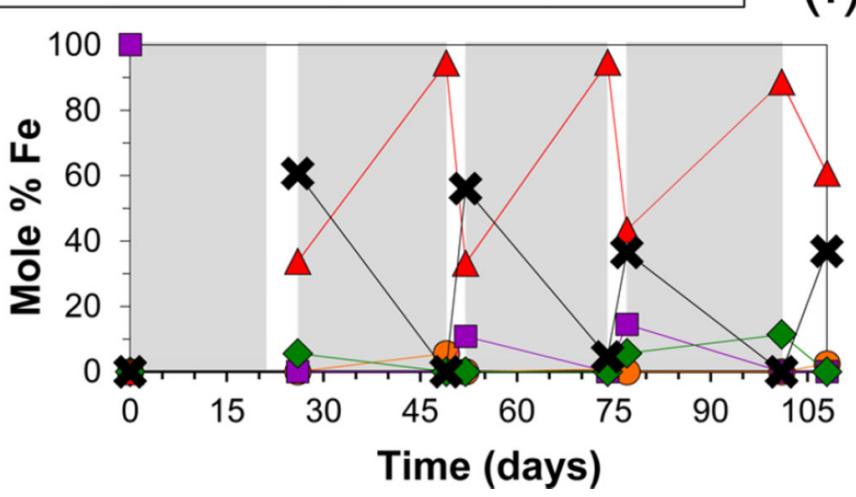

Impact of redox cycling, driven by introduction of glucose $(\mathrm{G})$ followed by air $\left(\mathrm{O}_{2}\right)$ on aqueous $\mathrm{Fe}(\mathrm{II})$ (a, b), solid-associated $\mathrm{Fe}$ (II) (c, d) and $\mathrm{Fe}$ (hydr)oxide mineralogy (e, f) in reactors containing lepidocrocite $(\mathrm{a}, \mathrm{c}, \mathrm{e})$ or ferrihydrite $(\mathrm{b}, \mathrm{d}, \mathrm{f})$ as the starting minerals. EXAFS spectra and fits used to generate e and $f$ are available in the SI. Anaerobic periods 
Redox Cycling: Glucose and $\mathrm{NO}_{3}$

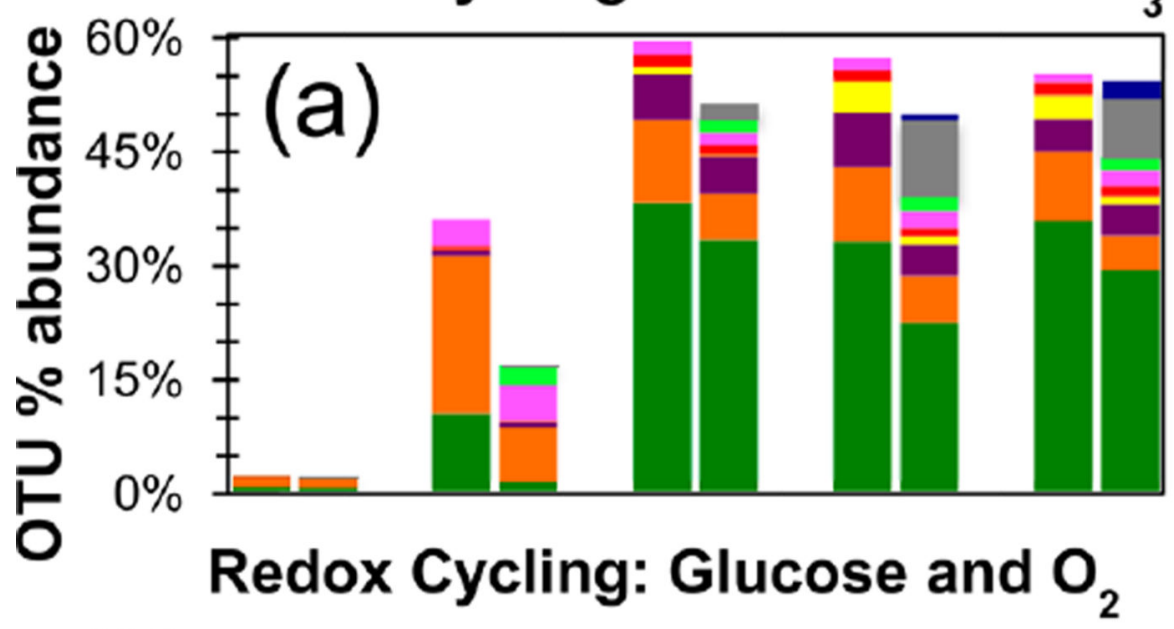

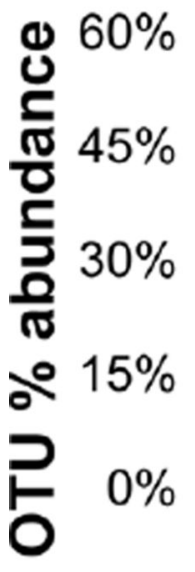

(b)

Figure 3.
Rhodocyclus

- Fusibacter

- Clostridium

Acetobacterium

- Caulobacter

Desulfomicrobium

Tolumonas

Mycoplana

Desulfovibrio

Dechloromonas

Desulfosporosinus

- Sporomusa

$\begin{array}{ccccc}\text { Day } & \text { Day } & \text { Day } & \text { Day } & \text { Day } \\ 0 & 21 & 49 & 74 & 101\end{array}$

- Geobacter

- Propionivibrio

Taxa enriched by more than 1\% ( 25 reads) after 108 days of redox cycling with glucose and nitrate (a), or glucose and air (b), in the presence of lepidocrocite (L) and ferrihydrite

(F) as the starting minerals. All taxa with functional classification are available in the SI. 